Florida International University FIU Digital Commons

$11-23-2004$

\title{
A comparison of the Kodaly method and the traditional method to determine pitch accuracy in grade 6 choral sight-singing
}

Merissa Amkraut

Florida International University

DOI: $10.25148 /$ etd.FI14032308

Follow this and additional works at: https://digitalcommons.fiu.edu/etd

Part of the Music Education Commons

\section{Recommended Citation}

Amkraut, Merissa, "A comparison of the Kodaly method and the traditional method to determine pitch accuracy in grade 6 choral sight-singing" (2004). FIU Electronic Theses and Dissertations. 1281.

https://digitalcommons.fiu.edu/etd/1281 
FLORIDA INTERNATIONAL UNIVERSITY

Miami, Florida

A COMPARISON OF THE KODALY METHOD AND THE TRADITIONAL

METHOD TO DETERMINE PITCH ACCURACY

IN GRADE 6 CHORAL SIGHT-SINGING

A thesis submitted in partial fulfillment of the

requirements for the degree of

MASTER OF SCIENCE

in

MUSIC EDUCATION

by

Merissa Amkraut

2004 
To: Dean R. Bruce Dunlap

College of Arts and Sciences

This thesis, written by Merissa Amkraut, and entitled A Comparison of the Kodaly Method and the Traditional Method to Determine Pitch Accuracy in Grade 6 Choral Sight-Singing, having been approved in respect to style and intellectual content, is referred to you for judgment.

We have read this thesis and recommend that it be approved.

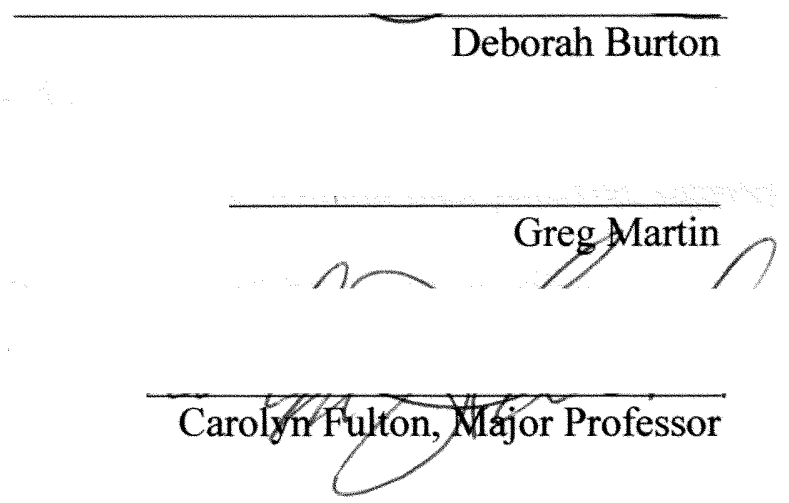

Date of Defense: November 23, 2004

The thesis of Merissa Amkraut is approved.

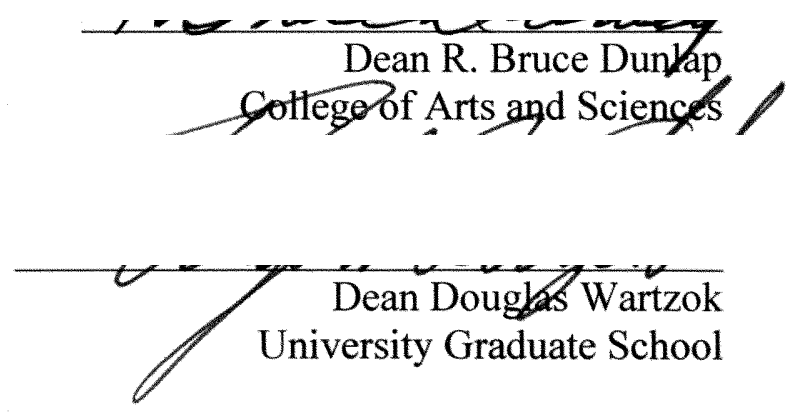

Florida International University, 2004 


\section{DEDICATION}

I dedicate this thesis to my parents and my brother, Ross. Without their patience, support and most of all love, the completion of this work would not have been possible. 


\section{ACKNOWLEDGMENTS}

I wish to thank the members of my committee for their support and patience. I certainly appreciate their guidance and support throughout this journey. Dr. Greg Martin's willingness to join my committee has been most appreciated. Dr. Deborah Burton was kind enough to give me insight into analyzing great music. Finally, I would like to thank my major professor, Dr. Carolyn Fulton. From our first meeting, she believed in my ideas and my work ethic and encouraged me during difficult times. I truly appreciate her time, effort and friendship.

I have found my coursework throughout the Music Education program to be stimulating and educational, providing me with the necessary tools to become a Master Educator. 


\section{ABSTRACT OF THE THESIS \\ SINGING \\ by \\ Merissa Amkraut \\ Florida International University, 2004 \\ Miami, Florida \\ Professor Carolyn Fulton, Major Professor}

A COMPARISON OF THE KODALY METHOD AND THE TRADITIONAL

METHOD TO DETERMINE PITCH ACCURACY IN GRADE 6 CHORAL SIGHT-

The purpose of this study was to determine which of the two methods is more appropriate to teach pitch discrimination to Grade 6 choral students to improve sight-singing note accuracy. This study consisted of three phases: pre-testing, instruction and post-testing. During the four week study, the experimental group received training using the Kodaly method while the control group received training using the traditional method. The pre and post tests were evaluated by three trained musicians. The analysis of the data utilized an independent $\mathrm{t}$-test and a paired $\mathrm{t}$-test with the methods of teaching (experimental and control) as a factor. Quantitative results suggest that the experimental subjects, those receiving Kodaly instruction at post-treatment showed a significant improvement in the pitch accuracy than the control group. The specific change resulted in the Kodaly method to be more effective in producing accurate pitch in sight-singing. 
CHAPTER

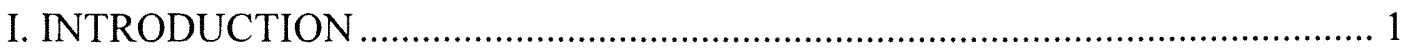

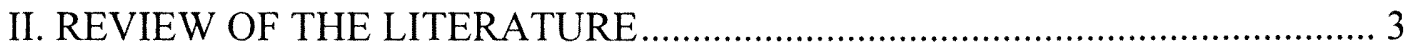

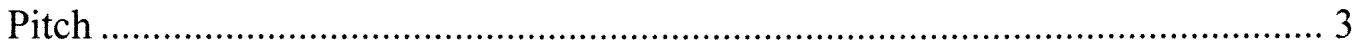

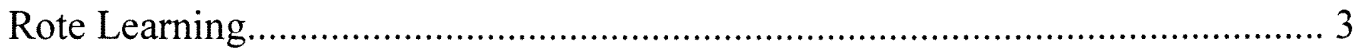

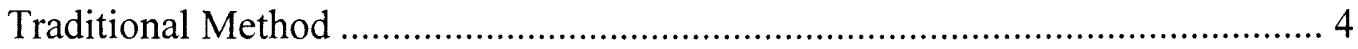

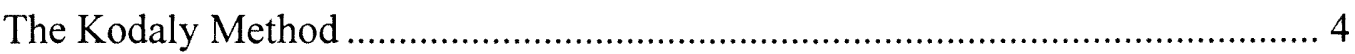

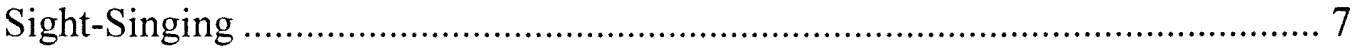

III. METHODOLOGY10

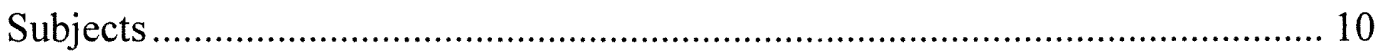

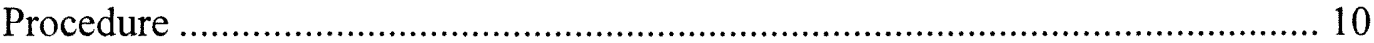

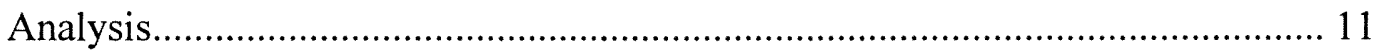

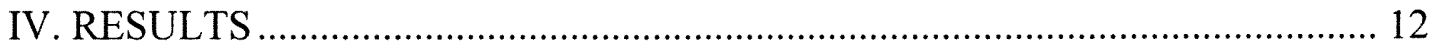

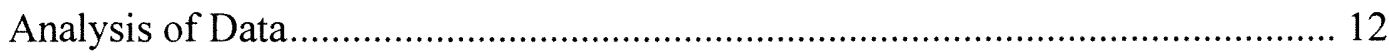

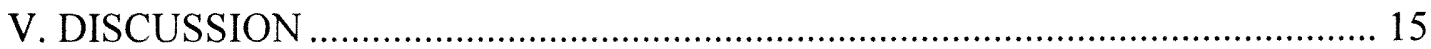

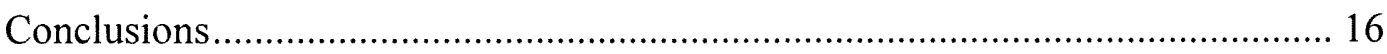

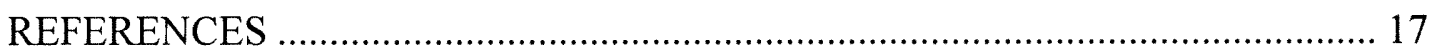

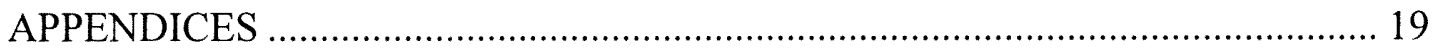




\section{Chapter 1}

\section{INTRODUCTION}

\section{Research Problem}

Grade 6 chorus is the beginning level of continued music study. It is often considered the culmination of musical concepts learned in elementary general music. The Sunshine State Standards provided to teachers includes reading and notation of music as a basic concept for Grade 6. Standard MU.A.3.3.1 states, "the student sight reads music in the bass and/or treble clefs written in simple and compound meters." This standard is solely an end result and there is not a suggested, uniform approach given to teachers as to which method will produce better intonation, the Kodaly method or the traditional method. Choral teachers are not instructed to use a particular teaching method for sightsinging. This research will measure the results of two different method of learning to determine the better approach to teaching correct pitch discrimination in sight-singing.

\section{Need for the Study}

This study is significant to the field of music education because teachers need to have a better understanding of the methodology associated with teaching sight-singing to sixth graders. Teachers are expected to have their performing groups participate in annual Music Performance Assessments in the area of sight-singing. This study will provide data that will aid choral teachers in determining which method is more suitable. Teachers must explore both the Kodaly method and the traditional method to determine which produces better results. This study will measure both methods and provide data that can be used by 
other teachers who may have difficulty teaching pitch accuracy in sight-singing to sixth graders. 
Chapter 2

\section{LITERATURE REVIEW}

Introduction

The research done for this review involves the study of both the Kodaly method and the traditional method when used as a teaching strategy in a Grade 6 Choral class. Sight-singing will be used as the assessment activity for determining the best method.

\section{Pitch}

The term "pitch" as defined in Songworks I: Singing in the Education of Children refers to the dimension of sound that we describe as relative highness of lowness. Seeing pitches notated on a staff conditions us to think of them as moving up and down, bring higher and lower than each other (Bennett and Bartholomew, 1997). Teachers should clearly define the terms used to describe pitch movement such as high and lower and up and down. Bennett and Bartholomew continue to say that the concept of vertical distance and movement is the conventional way of thinking about pitch. In their research, they included an example of an activity to use when teaching children to determine pitch movement. A melody graph can be made by having students connect the written notes with a line is a good visual representation of the changing directions and relative distances between the pitches of a melody (see Appendix A).

\section{Rote Learning}

Teaching music by ear, without the use of notation is known as the rote approach. This method, which has been used successfully by teachers who can read music as well 
as by those who cannot, has been a useful, but limited strategy for teaching music at all levels for many generations. Rote teaching is done through teacher modeling and student observation and imitation (Bennett and Bartholomew, 1997). Reading music is neither necessary to nor sufficient for being a musician; however, lack of music-reading skills limits the extent to which we can independently investigate unfamiliar material or literature. The advantage of rote learning is that teachers can continue to make music with students by teaching songs, guiding aural and vocal skills, stimulating interest in music and accomplish all these tasks effectively, without recourse to music reading (Bennett and Bartholomew, 1997).

\section{Traditional Method}

The traditional method can be described as a combination of rote learning and modeling. The traditional method involves teaching without overt reference to musical concepts (Apfelstadt, 1984). In a descriptive study by Johnson (1988), he found that the interval approach was most frequently used and although most of the choral educators agreed with a philosophy of music literacy, relatively little time was devoted to sightsinging. In this study, the use of pitch direction and intervallic note relationship will serve as the traditional teaching method.

The Kodaly Method

The Hungarian composer, Zoltan Kodaly (1882-1967) based his philosophy of music education on singing. The Kodaly technique asserts that singing is the foundation for broad musical literacy (Howard, 1996). Kodaly believes, "the human voice is an instrument provided by nature and is one that almost everyone can develop." In a study 
by Howard, he states that instruction in the Kodaly method should continue until the student is competent in the essentials of musicianship: sight-singing, dictation, ear training, part-hearing, harmony, form, and memory. In addition, Howard's research suggests that the incorporation of these concepts into the instructional classroom will provide better understanding of fundamental concepts improving the student's musicianship. Another study done by DeVries discusses the advantages of having Kodaly-based music programs in elementary schools. Kodaly-based music programs are formed around Kodaly's belief that 1) true music literacy - the ability to read, write and think music - is the right of every human; 2) music learning must begin with the voice; 3) the education of the musical ear must begin in primary grades if it is to be successful; 4) music skills and concepts necessary for musical literacy should be taught with folk music of the mother tongue; and 5) only music of unquestioned quality - both folk and composed should be used (DeVries, 2001). In DeVries' research he reevaluates the use of Kodaly and his experiences with using this method in his own elementary teaching. DeVries states, “Anyone who has taught a Kodaly-based music program will know just how successful it can be. From week to week, children's singing-particularly pitch improves; rhythmic skills improve significantly from year to year; music literacy develops; and children can perform music in increasingly complex parts."

Hand signs are physical gestures that represent solfa (Bennet and Bartholomew, 1997). Solfa syllables (also referred to as solfège or solfeggio) are used to teach young students the relationships between tones. The two main varieties of solfa are the fixed do and moveable do system. In the moveable do system, the syllables represent only the pitch relationships. Hand signs for this system originated in the late nineteenth century 
with John Curwen. Curwen created the hand signs as a way of showing the tones of the moveable do system (Bennett and Bartholomew, 1997). Kodaly borrowed the hand signs and emphasized their use in music education in Hungary. Many American music teachers have been using these hand signs in classrooms since the 1960s. According to Bennett and Bartholomew (1997), solfa syllables are preferable in teaching sight-singing for three primary reasons:

1) Solfa syllables are logically supported with hand signs (See Appendix B).

2) The vowel sounds of the solfa syllables are more compatible with good vocal production than those of the number system.

3) Numbers are used for many other purposes. In musical situations, they are used for meter, identifying measures, counting rhythms and names chords. Solfa syllables are better to use because they solely apply to the study of pitch relationships (p. 133).

Henry and Demorest (1994), investigated to determine the factors that contribute to sightsinging achievement in high school choirs. They distributed questionnaires regarding their music background and were given sight-singing exams. One group was taught using moveable do and the other group was taught using fixed do. Results showed no significant difference in achievement between the two groups. The answers from the questionnaires found that students with previous piano instruction achieved better sightsinging results (Henry and Demorest, 1994). In a descriptive study by May (1993), moveable $d o$ was the reading system used by $82.30 \%$ of the respondents and that $76.56 \%$ 
reported that they rehearsed melodic sight-reading between 30 and 36 weeks of the school year.

\section{Sight-singing}

Sight-singing technique can be developed on an informal, functional basis. During rehearsals, sight-singing functions as a whole-part guideline teaching both rhythm and pitch. Various patterns in music can be pointed out so that the students gain a concept that is transferable from one piece to another (Bennett and Bartholomew, 1997). When teaching sight-singing, teachers often rely on the use of the piano. Kodaly believed that voices are best accompanied by other voices and that we learn to sing better in tune when we match a voice to another voice rather than to an instrument (Choksy, 1988). In order to help students achieve musical independence from the piano, a sight-reading system that give singers a tool with which to approach the music needs to be selected (GuelkerCone, 1998). Guelker-Cone states that there are a range of systems available to teachers; however, the moveable do system, with a do-do scale for major keys and a la-la scale for minor keys has a number of advantages if it is used consistently. It should also be noted that Kodaly was an advocate of the moveable do system. She continues to say that students should be involved in reading choral music as soon as possible. The Kodaly method uses a number of activities to teach students to understand pitch relationships in order to be able to later read music. In Guelker-Cone's study, she clearly states the advantages of using the moveable $d o$ system over the fixed $d o$ system. The moveable do system highlights the harmonic function of each note in a scale. The recurring function of these syllables serves as an aid for sight-singing and composition analysis. The introduction of a sharp or flat alters the rhythm of the note in the number system. Instead 
of saying " $d o, d i, r e, r i \ldots$ " students using the number system or traditional method say, “one, sharp-one, two, sharp-two..." Students need to start practicing vocalises on moveable do syllables in order to develop an aural understanding of each syllable's relationship to other pitches (Guelker-Cone, 1998). In Henry's study (2001), she developed a vocal sight-reading inventory assessment tool that represents the skills involved in vocal sight-reading (Henry, 2001). She found that there was no sight-reading test available that a) represents fundamental pitch skills incorporated in most choral literature and sight-reading text-books; b) accommodates time constraints of secondary choral music directors; c) provides formative and summative evaluation information to teachers, students, and parents; and d) provides validity, reliability, or morning data. The Vocal Sight-Reading Inventory developed in this study was informed by the finding of previous research hand addressed questions raised by that research (Henry, 2001). Previous research confirmed the need for a strong vocal context for musical examples. Henry used scale patterns including do to $m i$, do to sol, or do to do because each begin and end within the same harmonic function. In her study, a percentage success rate was determined by dividing the number of pitches performed correctly by the number contained in the test. No significant difference between forms was found for 22 of the 28 pitch skills. In another study by Belmondo (1987), two different methods of tonal music reading instruction for high school choral students were compared. The methods were based on Edwin Gordon's theory or hierarchical levels of learning. The subjects were split into high and low aptitude groups based on their scores on the Tonal Imagery section of Gordon's Music Aptitude Profile (Grant and Norris, 1998). When tested on familiar major and minor tonal patterns, no significant differences were found for either 
treatments or aptitude levels. However, they found that when tested on unfamiliar patterns, significant differences between high and low aptitude students in the control group existed (Grant and Norris, 1998). 
Chapter 3

\section{METHODOLOGY}

\section{Subjects}

Participants for this study attend a middle school in south Florida. The subjects were two intact classes of Grade 6 choral students aging in range from 11-13 years. One class was the experimental group and the other class was the control group. The experimental group consisted of 39 students ( 3 boys and 36 girls). The control group had a total of 41 students ( 6 boys and 35 girls). A total of 80 sixth grade students took part in the study.

\section{Procedure}

This study consisted of three phases: pre-testing, instruction and post-testing and took place over four weeks. The first procedure of this study included a pre-test administered to both the experimental and the control group. The investigator administered the sight-singing test to both groups. The pre-test, based on the findings of Henry's investigation (2001) of the Vocal Sight-Reading Inventory (VSRI) consisted of diatonic scale passages with no altered tones. Students sang the example using "loo" syllable (without the use of Curwen hand signs). The pre-tests were audio recorded onto a mini-disk. An independent samples t-test was used to check for equivalence between the two groups. During the instructional phase (a four-week period), the experimental group received training using the Kodaly method, including hand signs and moveable $d o$. The control group received training using the traditional method or numeric scale degrees and 
pitch direction to determine which notes to sing. Sight-reading instruction for both groups consisted of two fifteen-minute lessons per week. Since this middle school functioned on a rotating block schedule, students met every other day for two hours. The sight-singing training was implemented during the first fifteen minutes of class (See Appendix C). At the completion of the four weeks, the same test based on the Vocal Sight-Reading Inventory was given to the experimental and control group as a post-test.

\section{Analysis}

Three different forms of assessment were used to analyze the data. Pre-test and post-test scores were analyzed by a panel of three trained musicians to score for accuracy. The mode of the three evaluators was used in the statistical analysis. A paired samples ttest was used to analyze the number of correct notes on the post-test and the pre-test. An independent samples t-test was done on the difference of the post-test and the pre-test to determine if pitch accuracy improved after four weeks of sight-reading instruction. 


\section{Chapter 4}

\section{RESULTS}

Three evaluators (all music teachers) were asked to evaluate each student's pitch accuracy. The judges listened to two performances of the students. The performances were randomized so that the judges could not identify which one was the pre-test and which one the post-test. They were asked to count the number of correct pitches heard. The maximum score was twenty-four correctly identified notes.

Two different forms of assessment were used to analyze the data. A paired samples t-test was conducted to measure whether students got a greater number of correct score on the post-test than on the pre-test. Also, an independent samples t-test was conducted on the difference of the post-test and pre-test to determine if pitch accuracy has improved among students after four weeks of instruction.

\section{Analysis of Data}

Prior to evaluating the data, an independent samples t-test was used to check for equivalence of the two groups. Table 1 compares the pre-test scores for each group.

\section{Independent Samples T-Test}

\begin{tabular}{|c|c|c|c|c|c|c|c|c|c|c|}
\hline & & \multicolumn{2}{|c|}{$\begin{array}{l}\text { Levene's Test } \\
\text { for Equality of } \\
\text { Variances }\end{array}$} & \multicolumn{7}{|c|}{ t-test for Equality of Means } \\
\hline & & \multirow[t]{2}{*}{$\mathbf{F}$} & \multirow[t]{2}{*}{ Sig. } & \multirow[t]{2}{*}{$\mathrm{t}$} & \multirow[t]{2}{*}{ df } & \multirow[t]{2}{*}{$\begin{array}{l}\text { Sig. (2- } \\
\text { tailed) }\end{array}$} & \multirow[t]{2}{*}{$\begin{array}{c}\text { Mean } \\
\text { Difference }\end{array}$} & \multirow[t]{2}{*}{$\begin{array}{l}\text { Std. Error } \\
\text { Difference }\end{array}$} & \multicolumn{2}{|c|}{$\begin{array}{c}95 \% \\
\text { Confidence } \\
\text { Interval of the } \\
\text { Difference }\end{array}$} \\
\hline & & & & & & & & & Lower & Upper \\
\hline Pre-test & $\begin{array}{l}\text { Equal } \\
\text { variances } \\
\text { assumed } \\
\text { Equal } \\
\text { variances } \\
\text { not assumed }\end{array}$ & .355 & .553 & $\begin{array}{l}1.625 \\
1.621\end{array}$ & $\begin{array}{r}78 \\
76.28 \\
9\end{array}$ & .108 & .777 & .478 & -.175 & 1.730 \\
\hline
\end{tabular}

Table 1- Comparison of pre-test scores to check for equivalence among both the experimental and control groups. 
The results indicated that, prior to instruction, there were no significant differences between students in the experimental group and students in the control group.

The investigator collected each answer given by students in the pre-test as well as the post-test. A paired samples t-test was conducted to evaluate and compare the students' improvement of pitch accuracy in sight-singing. Table 2 summarizes and compares the results of this investigation.

\section{Paired Samples T-Test}

\begin{tabular}{|c|c|c|c|c|c|c|c|c|c|}
\hline & \multicolumn{5}{|c|}{ Paired Differences } & \multirow[b]{3}{*}{$\mathrm{t}$} & \multirow[b]{3}{*}{ df } & \multirow{3}{*}{$\begin{array}{l}\text { Sig. (2- } \\
\text { tailed) }\end{array}$} \\
\hline & & \multirow[b]{2}{*}{ Mean } & \multirow{2}{*}{$\begin{array}{c}\text { Std. } \\
\text { Deviation }\end{array}$} & \multirow{2}{*}{$\begin{array}{l}\text { Std. } \\
\text { Error } \\
\text { Mean }\end{array}$} & \multicolumn{2}{|c|}{$\begin{array}{l}95 \% \text { Confidence } \\
\text { Interval of the } \\
\text { Difference }\end{array}$} & & & \\
\hline & & & & & Lower & Upper & & & \\
\hline Pair 1 & $\begin{array}{l}\text { Pre-test } \\
- \text { Post- } \\
\text { test }\end{array}$ & -8.282 & 4.668 & .747 & -9.795 & -6.769 & $11.081^{-}$ & 38 & .000 \\
\hline
\end{tabular}

Table 2- Paired Samples T-test of pre-test vs. post-test scores

Upon completion of four weeks of instruction, there was significant improvement in the number of correct notes sung among students from the experimental group. For the experimental group, the mean correct on the post-test $(\mathrm{M}=17.72, \mathrm{SD}=4.489)$ was significantly greater than the mean correct on the pre-test $(\mathrm{M}=9.44, \mathrm{SD}=2.245)$. There were no significant differences between the means of the total correct on the pre-test vs. the total correct on the post-test for the control group. The experimental group improved more than the control group. Table 3 compares the pre-test vs. post-test scores by group.

Paired Samples T-Test: Experimental Group

\begin{tabular}{|ll|r|r|r|r|}
\hline & & Mean & $\mathrm{N}$ & Std. Deviation & \multicolumn{1}{c|}{$\begin{array}{c}\text { Std. Error } \\
\text { Mean }\end{array}$} \\
\hline Pair 1 & Pre-test & 9.44 & 39 & 2.245 & .360 \\
Experimental & Post-test & 17.72 & 39 & 4.489 & .719 \\
\hline
\end{tabular}


Paired Samples T-Test: Control Group

\begin{tabular}{|c|c|c|c|c|c|}
\hline & & Mean & $\mathrm{N}$ & Std. Deviation & $\begin{array}{l}\text { Std. Error } \\
\text { Mean }\end{array}$ \\
\hline \multirow{2}{*}{$\begin{array}{l}\text { Pair 1 } \\
\text { Control }\end{array}$} & Pre-test & 8.66 & 41 & 2.032 & .317 \\
\hline & Post-test & 9.41 & 41 & 2.607 & .407 \\
\hline
\end{tabular}

Table 3- Paired samples t-test scores by group

An independent samples t-test was then conducted to compare the difference of the post-test scores minus the pre-test scores. Table 4 summarizes the results of this test.

Independent Samples T-Test (on the difference)

\begin{tabular}{|c|c|c|c|c|c|c|c|c|c|c|}
\hline & & \multicolumn{2}{|c|}{$\begin{array}{l}\text { Levene's Test } \\
\text { for Equality of } \\
\text { Variances }\end{array}$} & \multicolumn{7}{|c|}{ t-test for Equality of Means } \\
\hline & & \multirow[b]{2}{*}{$\mathrm{F}$} & \multirow[b]{2}{*}{ Sig. } & \multirow[b]{2}{*}{$\mathrm{t}$} & \multirow[b]{2}{*}{ df } & \multirow{2}{*}{$\begin{array}{l}\text { Sig. (2- } \\
\text { tailed) }\end{array}$} & \multirow{2}{*}{$\begin{array}{l}\text { Mean } \\
\text { Differe } \\
\text { nce }\end{array}$} & \multirow{2}{*}{$\begin{array}{c}\text { Std. } \\
\text { Error } \\
\text { Differe } \\
\text { nce }\end{array}$} & \multicolumn{2}{|c|}{$\begin{array}{l}95 \% \text { Confidence } \\
\text { Interval of the } \\
\text { Difference }\end{array}$} \\
\hline & & & & & & & & & Lower & Upper \\
\hline Difference & $\begin{array}{l}\text { Equal } \\
\text { variances } \\
\text { assumed } \\
\text { Equal } \\
\text { variances } \\
\text { not } \\
\text { assumed }\end{array}$ & 7.390 & .008 & 8.780 & 61.849 & .000 & 7.52595 & .85716 & $\begin{array}{r}5.8194 \\
7 \\
\\
5.7920 \\
9\end{array}$ & $\begin{array}{r}9.2324 \\
3 \\
\\
9.2598 \\
2\end{array}$ \\
\hline
\end{tabular}

Table 4- Independent samples t-test on the difference of the post-test vs. the pre-test

Based on the findings of the study, considerable evidence exists that the Kodaly training given to the experimental group produced a noticeable improvement in pitch accuracy during sight-singing activities. 
Chapter 5

\section{DISCUSSION}

The term "pitch" is widely used in music education every day. This dimension of sound can be related to the highness or lowness of notes. During this investigation, pitch was evaluated using a sight-singing assessment activity over a four-week period of time in which two different teaching methods were used. This investigation concludes with the statement that students instructed using the Kodaly system (with the Curwen hand signs) improved significantly in pitch accuracy while students who received instruction using the traditional teaching method (rote learning) showed no significant improvement. The findings in this study concur with the findings of DeVries, Guelker-Cone and Grant and Norris.

While instructing the sixth grade students, it was observed by the researcher that the group receiving training using the Kodaly method and hand signs could see and feel the movement of the pitches (high and low). The students receiving traditional rote instruction or echo singing had difficulty understanding the concept of high and low since no visual or physical experience occurred.

This study was limited to four weeks of instruction. A similar study could be conducted in the future to compare the pitch accuracy in sight-singing after an entire academic year (approximately thirty-six weeks) to determine improvement over a longer period of time. Teachers in south Florida can learn from this particular study since sightsinging is a requirement for grade 6 choral students. Perhaps going beyond the scope of this study, future studies will confirm the best teaching method to achieve maximum results in pitch accuracy and the long-term efficacy of the Kodaly method. 


\section{Conclusions}

As a result of the findings generated by this study, the following conclusions were inferred.

1. Students who received training using the Kodaly method achieved a greater significant advantage over students who received traditional instruction with regard to pitch accuracy in sight-singing activities.

2. Melodic perception of pitch can be acquired as a result of Kodaly training. This study was significant to the field of music education because there is a constant search for effective teaching methods. Educators should be made aware of the effects of each method so that students receive a high quality and effective music education. Based on the findings of this research, it was concluded that the Kodaly method tested in this study is an effective and valuable tool to aid in the pitch accuracy development in grade 6 choral sight-singing. 


\section{REFERENCES}

Apfelstadt, Hilary (1984). Effects of melodic perception instruction on pitch discrimination and vocal accuracy of kindergarten children. Journal of Research in Music Education, 32 (1), p.15-24.

Belmondo, D.J. (1987). A study of the effectiveness of partial synthesis as a readiness for tonal music reading. Dissertation Abstracts International, 47 (08), 2937 A.

Bennett, P. \& Bartholomew, D. (1997). Songworks I: Singing in the Education of Children. Belmont, California: Wadsworth Publishing Company.

Choksy, L. (1988). The Kodaly Method. Englewood Cliffs, New Jersey: Prentice Hall.

Demorest, Steven M. (1998). Sightsinging in the secondary choral ensemble: A Review of the Research. Bulletin of the Council for Research in Music Education, 137, p.1-15

DeVries, P. (2001). Reevaluating common Kodaly practices. Music Educators Journal, 88 , p. 24-7.

Grant, J.W. \& Norris, C. (1998). Choral Music Education: A Survey of Research 19821995. Bulletin of the Council for Research in Music Education, 135, p. 21-50.

Guelker-Cone, Leslie (1988). The unaccompanied choral rehearsal. Music Educators Journal, 85, p. 17-22.

Henry, Michele (2001). The Development of a Vocal Sight-Reading Inventory. Bulletin of the Council for Research in Music Education, 150, p. 21-33.

Henry, M. \& Demorest, S.M. (1994). Individual sight-singing achievement in successful choral ensembles: A preliminary study. Update: Applications of Research in Music Education, 13 (1), p. 4-8.

Howard, Pricilla M. (1996). Kodaly strategies for instrumental teachers. Music Educators Journal, 82, p. 27-33.

Johnson, G.J.B. (1988). A descriptive study of the pitch-reading methods and the amount of time utilized to teach sight-singing by high school choral teachers in the north central region of the American Choral Directors Association. Unpublished master's thesis, University of Nebraska, Lincoln.

May, J.A. (1993). A description of current practices in the teaching of choral melody reading in the high schools of Texas. (Doctoral dissertation, University of Houston, 1993). Dissertation Abstracts International, 54, 856A. 
Suero, Jetzabel (2003). Effect of the Kodaly approach as an aid to the development of pitch discrimination of first grade students. Unpublished master's thesis, Florida International University, Florida. 
Appendix A

Melody Graph for "Mary Had a Little Lamb" 


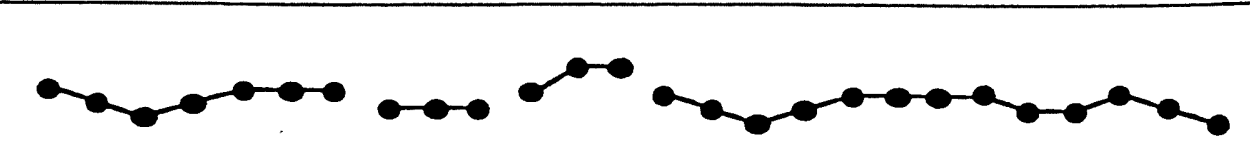

From Songworks I, Singing in the Education of Children $1^{\text {st }}$ edition by BENNETT/BARTHOLOMEW. (C) 1997. Reprinted with permission of Wadsworth, a division of Thomson Learning: www.thomsonrights.com Fax 800-730-2215 (See Appendix F) 
Appendix B

Curwen Hand Signs Adapted by Kodaly 


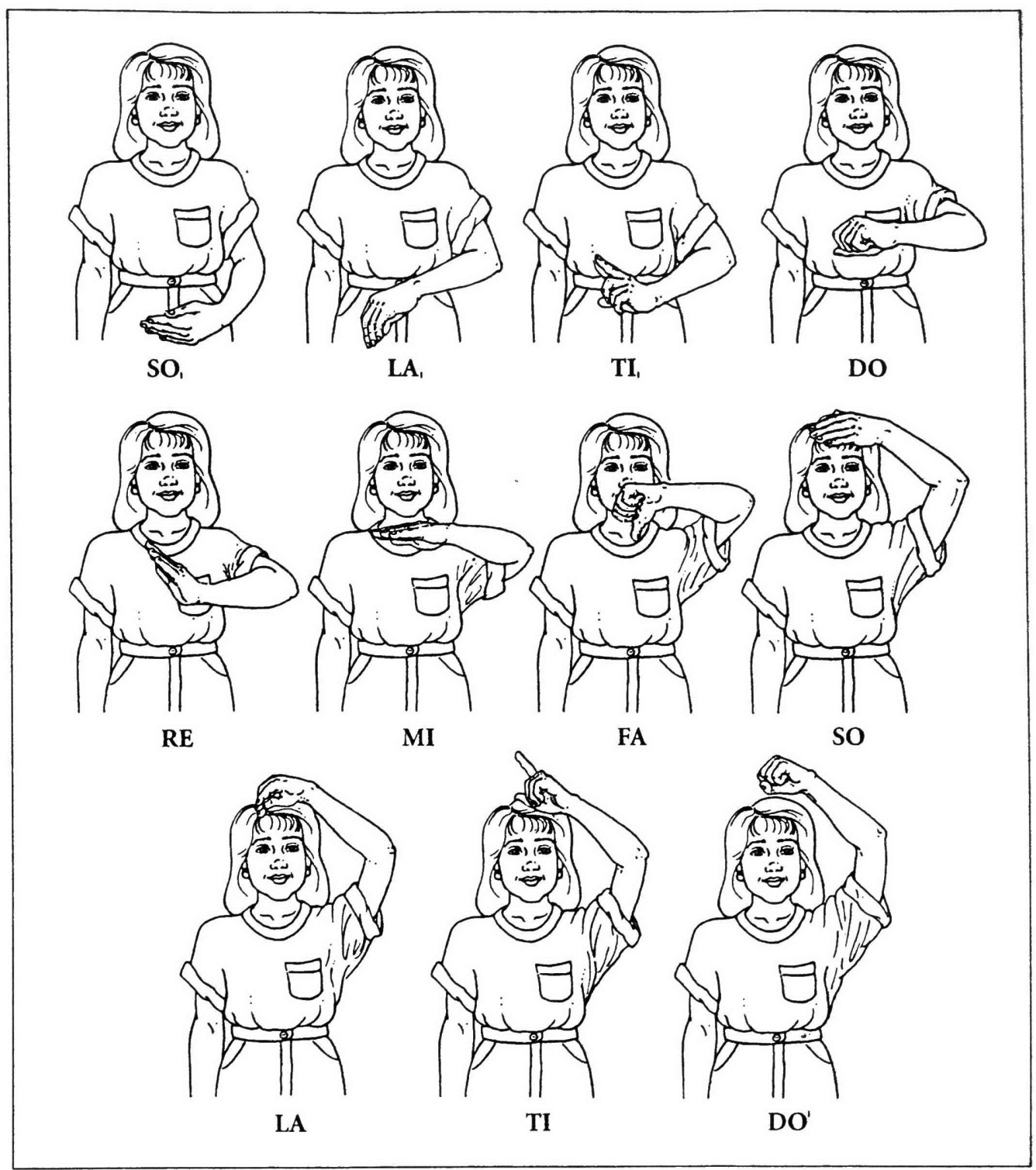

From Songworks I, Singing in the Education of Children $1^{\text {st }}$ edition by BENNETT/BARTHOLOMEW. (C) 1997. Reprinted with permission of Wadsworth, a division of Thomson Learning: www.thomsonrights.com Fax 800-730-2215 (See Appendix F) 
Appendix C

Lesson Plans 


\section{Sight-Singing Lesson Plan}

Week 1

\begin{tabular}{|c|c|c|c|}
\hline Day 1 & DATE: & Day 2 & DATE: \\
\hline Objective: & \multirow{3}{*}{$\begin{array}{l}\text { 1. Students will be able } \\
\text { to sing } d o, \text { re, } t i \text { while } \\
\text { reading music } \\
\text { notation. } \\
\text { 2. Students will be able } \\
\text { to visually recognize } \\
\text { and sing repeated } \\
\text { notes. }\end{array}$} & Objective: & \multirow{3}{*}{$\begin{array}{l}\text { 1. Students will be } \\
\text { able to sing do, } \\
r e, m i, f a, t i \text { while } \\
\text { reading music } \\
\text { notation. } \\
\text { 2. Students will be } \\
\text { able to determine } \\
\text { the pitch direction } \\
\text { of given notes } \\
\text { using full body } \\
\text { movements. }\end{array}$} \\
\hline $\begin{array}{l}\text { Focus: } \\
d o, r e, t i\end{array}$ & & $\begin{array}{l}\text { Focus: } \\
d o, r e, m i \\
f a, t i\end{array}$ & \\
\hline $\begin{array}{l}\text { Materials: } \\
\text { Example A }\end{array}$ & & $\begin{array}{l}\text { Materials: } \\
\text { Example B }\end{array}$ & \\
\hline $\begin{array}{l}\text { Activities: } \\
\text { Kodaly }\end{array}$ & $\begin{array}{l}\text { 1. Teacher explains that } \\
d o \text { is the given note } \\
\text { in each example. } \\
\text { 2. Teacher models hand } \\
\text { sign for } d o, r e, t i \text {. } \\
\text { 3. Students do } \\
\text { "Example A" using } \\
\text { only hand-signs while } \\
\text { teacher plays pitches } \\
\text { on piano. } \\
\text { 4. Students sing } \\
\text { example on "loo" } \\
\text { syllable using hand } \\
\text { signs. } \\
\text { 5. Students sing } \\
\text { example using } \\
\text { solfége syllables and } \\
\text { hand signs. }\end{array}$ & $\begin{array}{l}\text { Activities: } \\
\text { Kodaly }\end{array}$ & $\begin{array}{l}\text { 1. Review sound (on } \\
\text { piano) and pitch } \\
\text { direction for } d o \text {, } \\
\text { re, } t \text {. } \\
\text { 2. Ask students, } \\
\text { "Which is the } \\
\text { highest sounding } \\
\text { pitch learned so } \\
\text { far?" answer: re, } \\
\text { because } t i \text { is } \\
\text { being taught as } \\
\text { scale degree } 7 \\
\text { under the root. } \\
\text { Teacher models } \\
\text { body movements } \\
\text { for "Example A" } \\
\text { 4. Students stand up } \\
\text { and sing } \\
\text { "Example A" } \\
\text { with body } \\
\text { movements. } \\
\text { 5. Teacher } \\
\text { introduces hand } \\
\text { signs for mi and } \\
\text { fa. } \\
\text { 6. Students echo } \\
\text { sing as teacher } \\
\text { sings } d o, r e, m i, \\
f a \text { patterns using } \\
\text { hand signs } \\
\text { (improvisation). }\end{array}$ \\
\hline
\end{tabular}




\begin{tabular}{|c|c|c|c|}
\hline & & & $\begin{array}{l}\text { 7. Students figure } \\
\text { out hand signs for } \\
\text { "Example B" } \\
\text { individually. } \\
\text { 8. Teacher gives } \\
\text { starting pitch for } \\
\text { do. } \\
\text { 9. Students sing } \\
\text { example on "loo" } \\
\text { syllable using } \\
\text { hand signs. } \\
\text { 10. Students sing } \\
\text { Example B using } \\
\text { solfége and hand } \\
\text { signs. }\end{array}$ \\
\hline $\begin{array}{l}\text { Activities: } \\
\text { Traditional }\end{array}$ & $\begin{array}{l}\text { 1. Teacher explains that } \\
\text { "one" is the given } \\
\text { note in each example, } \\
\text { followed by } 2 \text { going } \\
\text { up and } 7 \text { going down } \\
\text { (say "sev" for seven). } \\
\text { 2. Teacher explains that } \\
\text { the notes on the staff } \\
\text { can be sung by } \\
\text { "connecting the } \\
\text { dots". } \\
\text { 3. Students look at } \\
\text { "Example A" and } \\
\text { point out repeated } \\
\text { notes and notes that } \\
\text { move up or down. } \\
\text { 4. Teacher plays } \\
\text { example one line at a } \\
\text { time on piano while } \\
\text { students track music } \\
\text { for repeated notes. } \\
\text { 5. Students sing } \\
\text { example on "loo" } \\
\text { syllable. } \\
\text { 6. Students sing } \\
\text { example using } \\
\text { numbers. }\end{array}$ & $\begin{array}{l}\text { Activities: } \\
\text { Traditional }\end{array}$ & $\begin{array}{l}\text { 1. Review sound (on } \\
\text { piano) and pitch } \\
\text { direction for note } \\
1 \text { (given), } 2 \text { and } 7 . \\
\text { 2. Teacher models } \\
\text { body movements } \\
\text { for "Example A" } \\
\text { 3. Students stand up } \\
\text { and sing one line } \\
\text { with body } \\
\text { movements. } \\
\text { 4eacher explains } \\
\text { pitch direction for } \\
\text { new notes. } \\
\text { 5. Teacher plays } \\
\text { example on piano } \\
\text { while students } \\
\text { track music. } \\
\text { 6. Students sing } \\
\text { example on "loo" } \\
\text { syllable. } \\
\text { 7. Students sing } \\
\text { example using } \\
\text { numbers. }\end{array}$ \\
\hline
\end{tabular}


Example A
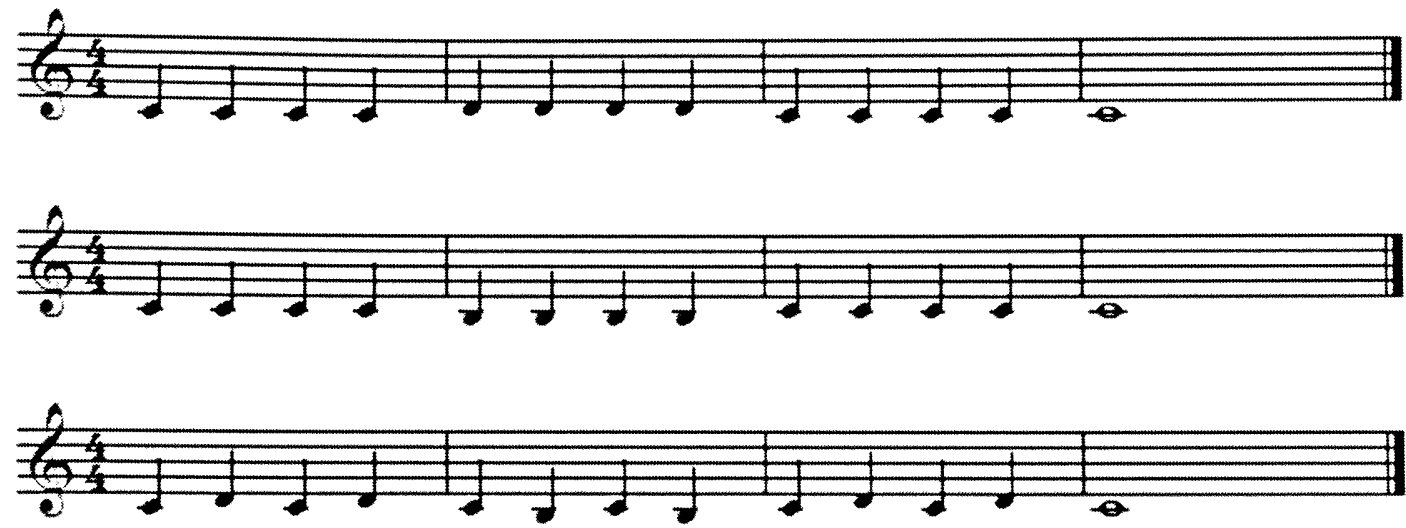
Example B
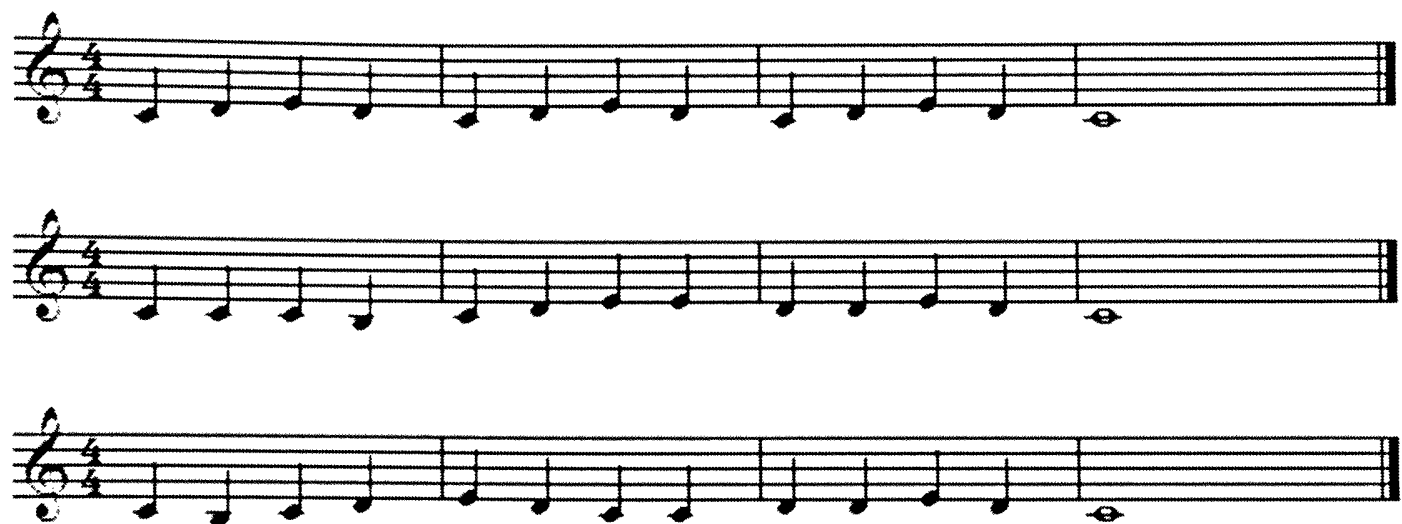


\section{Sight-Singing Lesson Plan}

Week 2

\begin{tabular}{|c|c|c|c|}
\hline Day 1 & DATE: & Day 2 & DATE: \\
\hline Objective: & \multirow{3}{*}{$\begin{array}{l}\text { 1. Students will be able } \\
\text { to recognize scale } \\
\text { movement. } \\
\text { 2. Students will be able } \\
\text { to sight-sing an } \\
\text { example containing } \\
\text { "skipping" intervals } \\
\text { of root, } 3^{\text {rd }} \text { and } 5^{\text {th }} \text { and } \\
\text { scale motion. }\end{array}$} & Objective: & \multirow{3}{*}{$\begin{array}{l}\text { 1. Students will be } \\
\text { able to determine } \\
\text { scale movement } \\
\text { and in which } \\
\text { direction (up or } \\
\text { down). } \\
\text { 2. Students will be } \\
\text { able to accurately } \\
\text { sing scale } \\
\text { movement from } \\
\text { do-la or scale } \\
\text { degrees1-6. }\end{array}$} \\
\hline $\begin{array}{l}\text { Focus: } \\
d o, r e, m i \\
f a, \text { sol }\end{array}$ & & $\begin{array}{l}\text { Focus: } \\
\text { do, re, mi, } \\
\text { fa, sol, la }\end{array}$ & \\
\hline $\begin{array}{l}\text { Materials: } \\
\text { Example C }\end{array}$ & & $\begin{array}{l}\text { Materials: } \\
\text { Example D }\end{array}$ & \\
\hline $\begin{array}{l}\text { Activities: } \\
\text { Kodaly }\end{array}$ & $\begin{array}{l}\text { 1. Teacher writes } \\
\text { solfége on the board } \\
\text { in contour notation } \\
\text { for "Example C". } \\
\text { 2. Teacher introduces } \\
\text { and models hand sign } \\
\text { for new note sol. } \\
\text { 3. Students sing } \\
\text { "Example C" contour } \\
\text { notation using } \\
\text { "hmm" and correct } \\
\text { hand signs. } \\
\text { 4. Teacher sings the } \\
\text { song through using } \\
\text { solfége. } \\
\text { 5. Students sing the } \\
\text { song using solfége } \\
\text { and correct hand } \\
\text { signs. }\end{array}$ & $\begin{array}{l}\text { Activities: } \\
\text { Kodaly }\end{array}$ & $\begin{array}{l}\text { 1. Teacher will } \\
\text { explain that there } \\
\text { is a new note. } \\
\text { 2. Students will sing } \\
\text { example using } \\
\text { solfége and sing } \\
\text { "hmm" for new } \\
\text { note. } \\
\text { 3. Teacher will model } \\
\text { hand sign for new } \\
\text { note "la". } \\
\text { 4. Students will give } \\
\text { hand signs for } \\
\text { "Example D" } \\
\text { while teacher sings } \\
\text { using solfege. } \\
\text { 5. Students will sing } \\
\text { using "hmm" } \\
\text { while doing hand } \\
\text { signs. } \\
\text { 6. Students will sing } \\
\text { "Example D" } \\
\text { using hand signs } \\
\text { and solfége } \\
\text { syllables. }\end{array}$ \\
\hline
\end{tabular}




\begin{tabular}{|c|c|c|c|}
\hline $\begin{array}{l}\text { Activities: } \\
\text { Traditional }\end{array}$ & $\begin{array}{l}\text { 1. Teacher writes } \\
\text { contour notation on } \\
\text { the board "Example } \\
\text { C" using circles. } \\
\text { 2. Teacher introduces } \\
\text { new note 5and } \\
\text { explains that it is one } \\
\text { note above } 6 . \\
\text { 3. Students sing } \\
\text { "Example C" contour } \\
\text { notation using } \\
\text { "hmm". } \\
\text { 4. Teacher sings the } \\
\text { song through using } \\
\text { scale degree numbers } \\
\text { while students track } \\
\text { each note. } \\
\text { 5. Students sing the } \\
\text { song using numbers. }\end{array}$ & $\begin{array}{l}\text { Activities: } \\
\text { Traditional }\end{array}$ & $\begin{array}{l}\text { 1. Teacher will } \\
\text { explain that there } \\
\text { is a new note. } \\
\text { 2. Teacher will draw } \\
\text { melody graph } \\
\text { showing pitch } \\
\text { direction for } \\
\text { "Example D". } \\
\text { 3. Teacher will } \\
\text { explain that new } \\
\text { note "6" is higher } \\
\text { than 5. } \\
\text { 4. Students will } \\
\text { echo-sing } \\
\text { "Example D" } \\
\text { using "loo" } \\
\text { 5. Students will sing } \\
\text { "Example D } \\
\text { using numbers. } \\
\text { 6. Students will } \\
\text { identify measures } \\
\text { that have upward } \\
\text { and downward } \\
\text { scale motion. }\end{array}$ \\
\hline
\end{tabular}


Example C

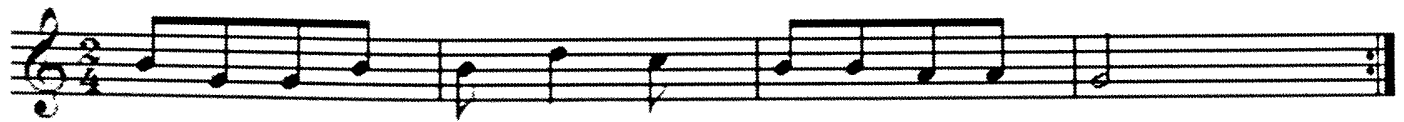

Whist - le, Daugh-ter, whist $-\mathrm{le}, \quad$ and you shall have a cow. 
Example D

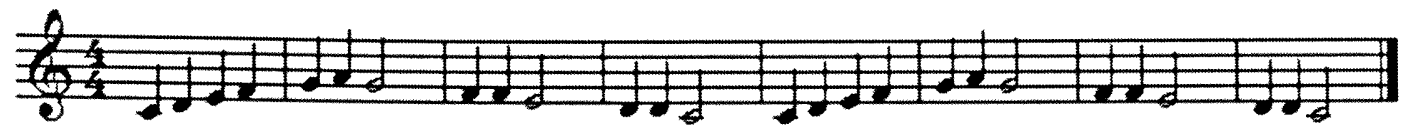

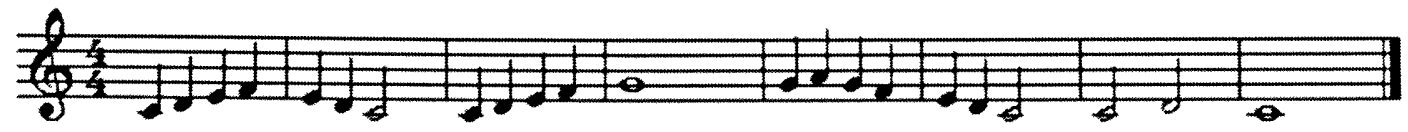




\section{Sight-Singing Lesson Plan}

Week 3

\begin{tabular}{|c|c|c|c|}
\hline Day 1 & DATE: & Day 2 & DATE: \\
\hline Objective: & \multirow{3}{*}{$\begin{array}{l}\text { 1. Students will be able } \\
\text { to sing } d o, r e, m i, f a \text {, } \\
\text { sol, la, } t i \text { while } \\
\text { reading music } \\
\text { notation. } \\
\text { 2. Students will be able } \\
\text { to visually recognize } \\
\text { and sing repeated } \\
\text { notes. } \\
\text { 3. Students will be able } \\
\text { to identify pitch } \\
\text { direction of notation }\end{array}$} & Objective: & \multirow{3}{*}{$\begin{array}{l}\text { 1. Students will be } \\
\text { able to sing } d o, \\
r e, m i, f a, \text { sol, } l a, \\
t i \text { while reading } \\
\text { music notation. } \\
\text { 2. Students will be } \\
\text { able to identify } \\
\text { pitch direction of } \\
\text { notation }\end{array}$} \\
\hline $\begin{array}{l}\text { Focus: } \\
\text { do, re, mi, } \\
\text { fa, sol, la, } t i\end{array}$ & & $\begin{array}{l}\text { Focus: } \\
\text { do, re, mi, } \\
\text { fa, sol, la, } t i\end{array}$ & \\
\hline $\begin{array}{l}\text { Materials: } \\
\text { Example E }\end{array}$ & & $\begin{array}{l}\text { Materials: } \\
\text { Example F }\end{array}$ & \\
\hline $\begin{array}{l}\text { Activities: } \\
\text { Kodaly }\end{array}$ & $\begin{array}{l}\text { 1. Teacher explains that } \\
\text { do is the given note in } \\
\text { each example. } \\
\text { 2. Teacher models hand } \\
\text { sign for } d o, r e, m i, f a \text {, } \\
\text { sol, la, ti. } \\
\text { 3. Students do } \\
\text { "Example E" using } \\
\text { only hand-signs while } \\
\text { teacher plays pitches } \\
\text { on piano. } \\
\text { 4. Students sing } \\
\text { example on "loo" } \\
\text { syllable using hand } \\
\text { signs. } \\
\text { 5. Students sing } \\
\text { example using } \\
\text { solfége syllables and } \\
\text { hand signs. }\end{array}$ & $\begin{array}{l}\text { Activities: } \\
\text { Kodaly }\end{array}$ & $\begin{array}{l}\text { 1. Review sound (on } \\
\text { piano) and pitch } \\
\text { direction for } d o \text {, } \\
r e, m i, f a, \text { sol, la, } \\
\text { ti. } \\
\text { 2. Explain use of } t i \\
\text { below root and as } \\
\text { pitch seven } \\
\text { 3. Teacher } \\
\text { introduces hand } \\
\text { signs for } t i \text { above } \\
\text { head. } \\
\text { 4. Students echo } \\
\text { sing as teacher } \\
\text { sings } d o, \text { re, mi, } \\
\text { fa, sol, la, } t i \\
\text { patterns using } \\
\text { hand signs } \\
\text { (improvisation). } \\
\text { 5. Teacher gives } \\
\text { starting pitch for } \\
\text { do. } \\
\text { 6. Students sing } \\
\text { example on "loo" } \\
\text { syllable using } \\
\text { hand signs. } \\
\text { 7. Students sing } \\
\text { Example F using } \\
\text { solfége and hand } \\
\text { signs. }\end{array}$ \\
\hline
\end{tabular}




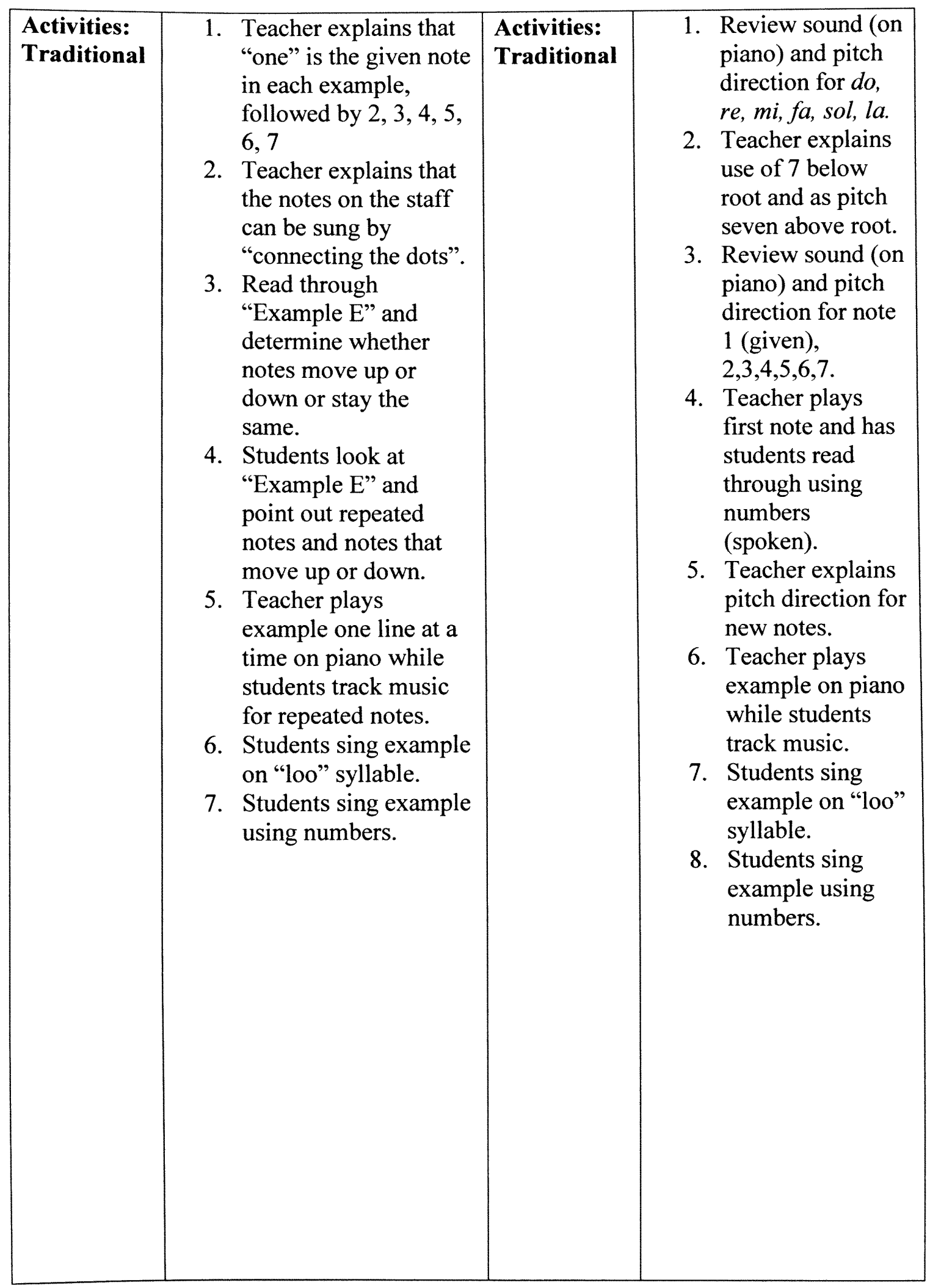


Example E

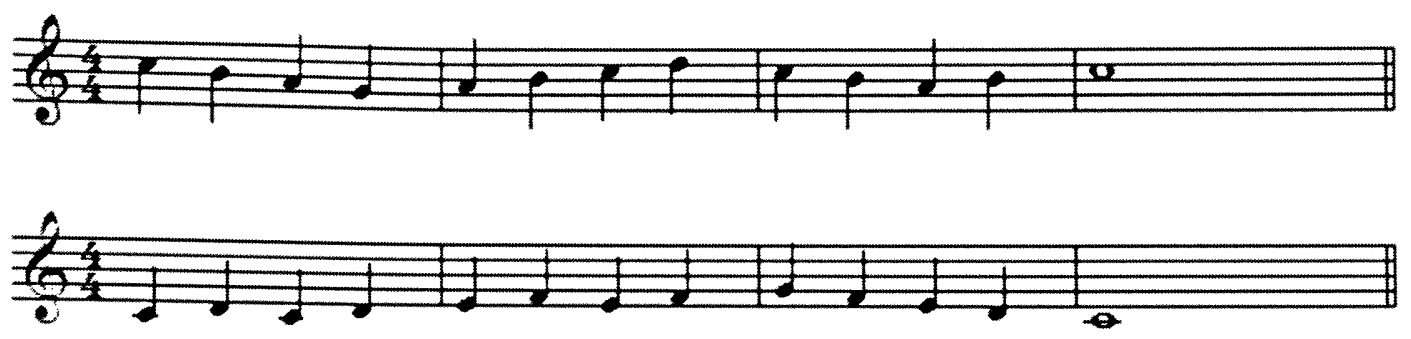


Example F
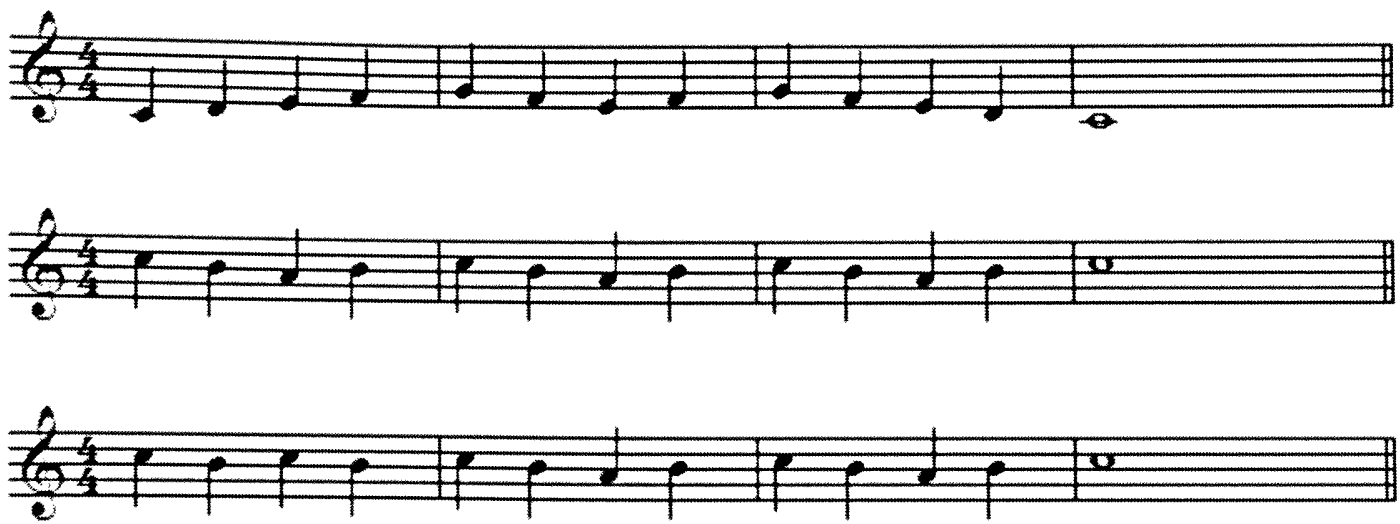
Sight-Singing Lesson Plan

Week 4

\begin{tabular}{|c|c|c|c|}
\hline Day 1 & DATE: & Day 2 & DATE: \\
\hline Objective: & \multirow{3}{*}{$\begin{array}{l}\text { 1. Students will be able } \\
\text { to sing do, re, mi, fa, } \\
\text { sol, la while reading } \\
\text { music notation. } \\
\text { 2. Students will be able } \\
\text { to visually recognize } \\
\text { and sing repeated } \\
\text { notes. } \\
\text { 3. Students will be able } \\
\text { to identify pitch } \\
\text { direction of notation }\end{array}$} & Objective: & \multirow{3}{*}{$\begin{array}{l}\text { 1. Students will be } \\
\text { able to sing } d o, \\
r e, m i, f a, t i \text { while } \\
\text { reading music } \\
\text { notation. } \\
\text { 2. Students will be } \\
\text { able to identify } \\
\text { pitch direction of } \\
\text { notation }\end{array}$} \\
\hline $\begin{array}{l}\text { Focus: } \\
\text { do, re, mi, } \\
\text { fa, sol, la, }\end{array}$ & & $\begin{array}{l}\text { Focus: } \\
\text { do, re, mi, } \\
\text { fa, sol, la, } t i\end{array}$ & \\
\hline $\begin{array}{l}\text { Materials: } \\
\text { Example G }\end{array}$ & & $\begin{array}{l}\text { Materials: } \\
\text { Example H }\end{array}$ & \\
\hline $\begin{array}{l}\text { Activities: } \\
\text { Kodaly }\end{array}$ & $\begin{array}{l}\text { 1. Teacher explains that } \\
\text { do is the given note } \\
\text { in each example. } \\
\text { 2. Teacher models hand } \\
\text { sign for } d o, \text { re, fa, } \\
\text { sol, la. } \\
\text { 3. Students do } \\
\text { "Example G" using } \\
\text { only hand-signs while } \\
\text { teacher plays pitches } \\
\text { on piano. } \\
\text { 4. Students sing } \\
\text { example on "loo" } \\
\text { syllable using hand } \\
\text { signs. } \\
\text { 5. Students sing } \\
\text { example using } \\
\text { solfége syllables and } \\
\text { hand signs. }\end{array}$ & $\begin{array}{l}\text { Activities: } \\
\text { Kodaly }\end{array}$ & $\begin{array}{l}\text { 1. Review sound (on } \\
\text { piano) and pitch } \\
\text { direction for } d o \text {, } \\
r e, m i, \text { fa, sol, la. } \\
\text { 2. Teacher reviews } \\
t i \text { at the top of the } \\
\text { scale. } \\
\text { 3. Students echo } \\
\text { sing as teacher } \\
\text { sings } d o, \text {, } r \text {, mi, } \\
\text { fa, sol, la, } t i \\
\text { patterns using } \\
\text { hand signs } \\
\text { (improvisation). } \\
\text { 4. Students figure } \\
\text { out hand signs for } \\
\text { "Example H" } \\
\text { individually. } \\
\text { 5. Teacher gives } \\
\text { starting pitch for } \\
\text { do. } \\
\text { 6. Students sing } \\
\text { example on "loo" } \\
\text { syllable using } \\
\text { hand signs. } \\
\text { 7. Students sing } \\
\text { Example H using } \\
\text { solfége and hand } \\
\text { signs. }\end{array}$ \\
\hline
\end{tabular}




\begin{tabular}{|c|c|c|c|}
\hline $\begin{array}{l}\text { Activities: } \\
\text { Traditional }\end{array}$ & $\begin{array}{l}\text { 1. Teacher explains that } \\
\text { "one" is the given } \\
\text { note in each example, } \\
\text { followed by } 2,3,4,5 \text {, } \\
6, \\
\text { 2. Teacher explains that } \\
\text { the notes on the staff } \\
\text { can be sung by } \\
\text { "connecting the dots". } \\
\text { 3. Read through } \\
\text { "Example G" and } \\
\text { determine whether } \\
\text { notes move up or } \\
\text { down or stay the } \\
\text { same. } \\
\text { 4. Students look at } \\
\text { "Example G" and } \\
\text { point out repeated } \\
\text { notes and notes that } \\
\text { move up or down. } \\
\text { 5. Teacher plays } \\
\text { example one line at a } \\
\text { time on piano while } \\
\text { students track music } \\
\text { for repeated notes. } \\
\text { 6. Students sing example } \\
\text { on "loo" syllable. } \\
\text { 7. Students sing example } \\
\text { using numbers. }\end{array}$ & $\begin{array}{l}\text { Activities: } \\
\text { Traditional }\end{array}$ & 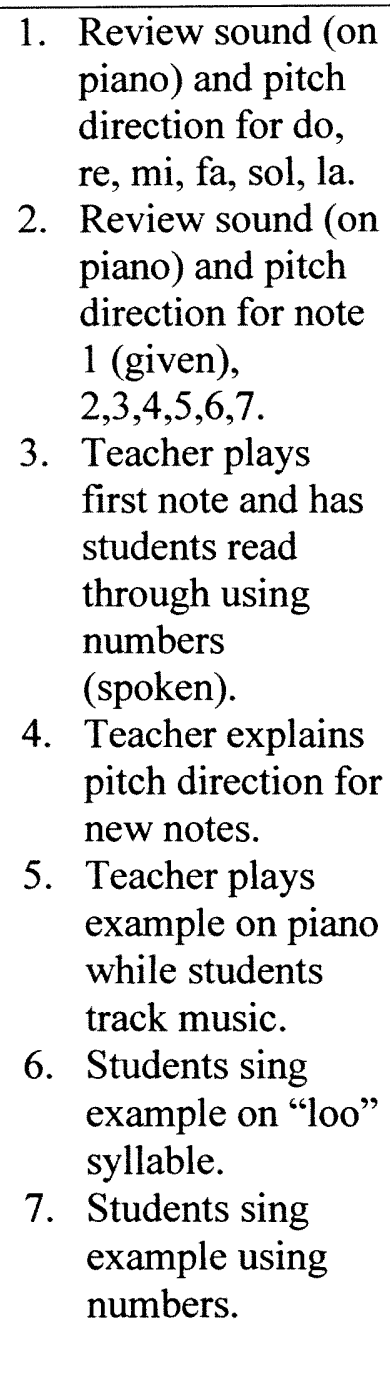 \\
\hline
\end{tabular}




\section{Example G}
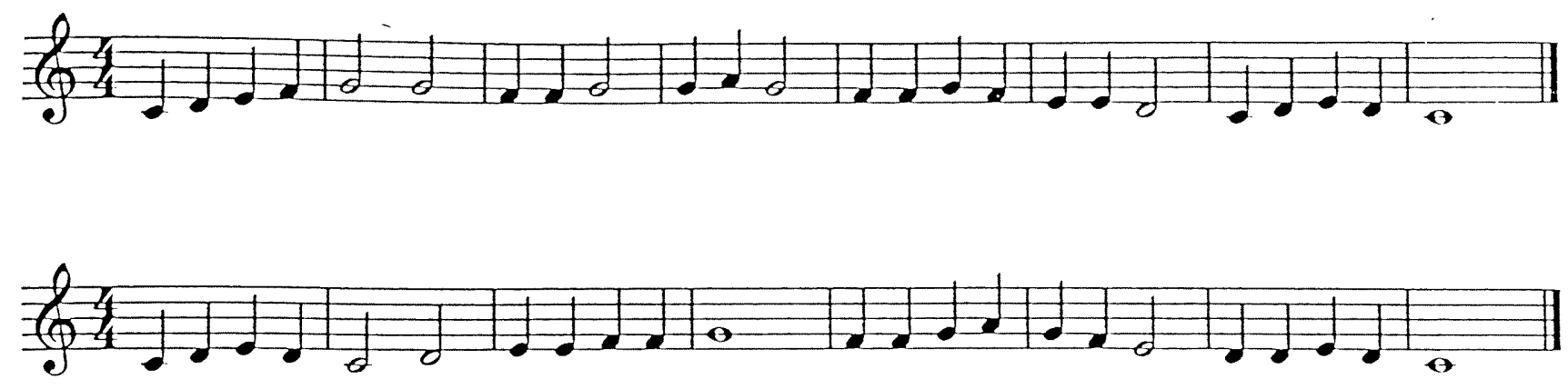
Example H
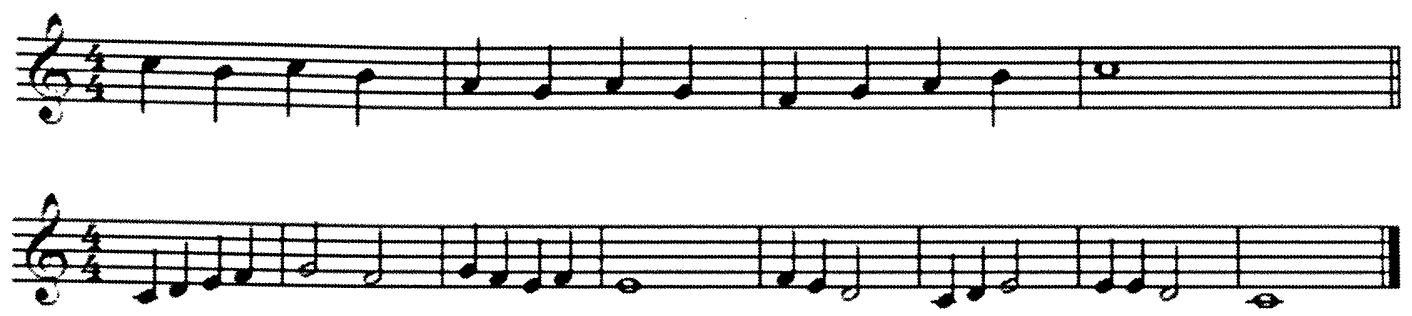

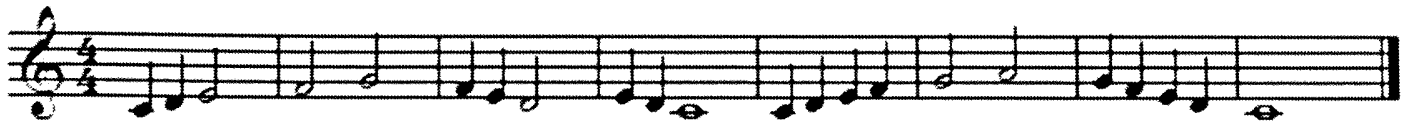


Appendix D

Components of the Vocal Sight Reading Inventory 


\section{Components of the Vocal Sight-Reading Inventory}

Henry, Michele (2001) Bulletin of the Council for Research in Music Education

Examples of component pitch skill patterns
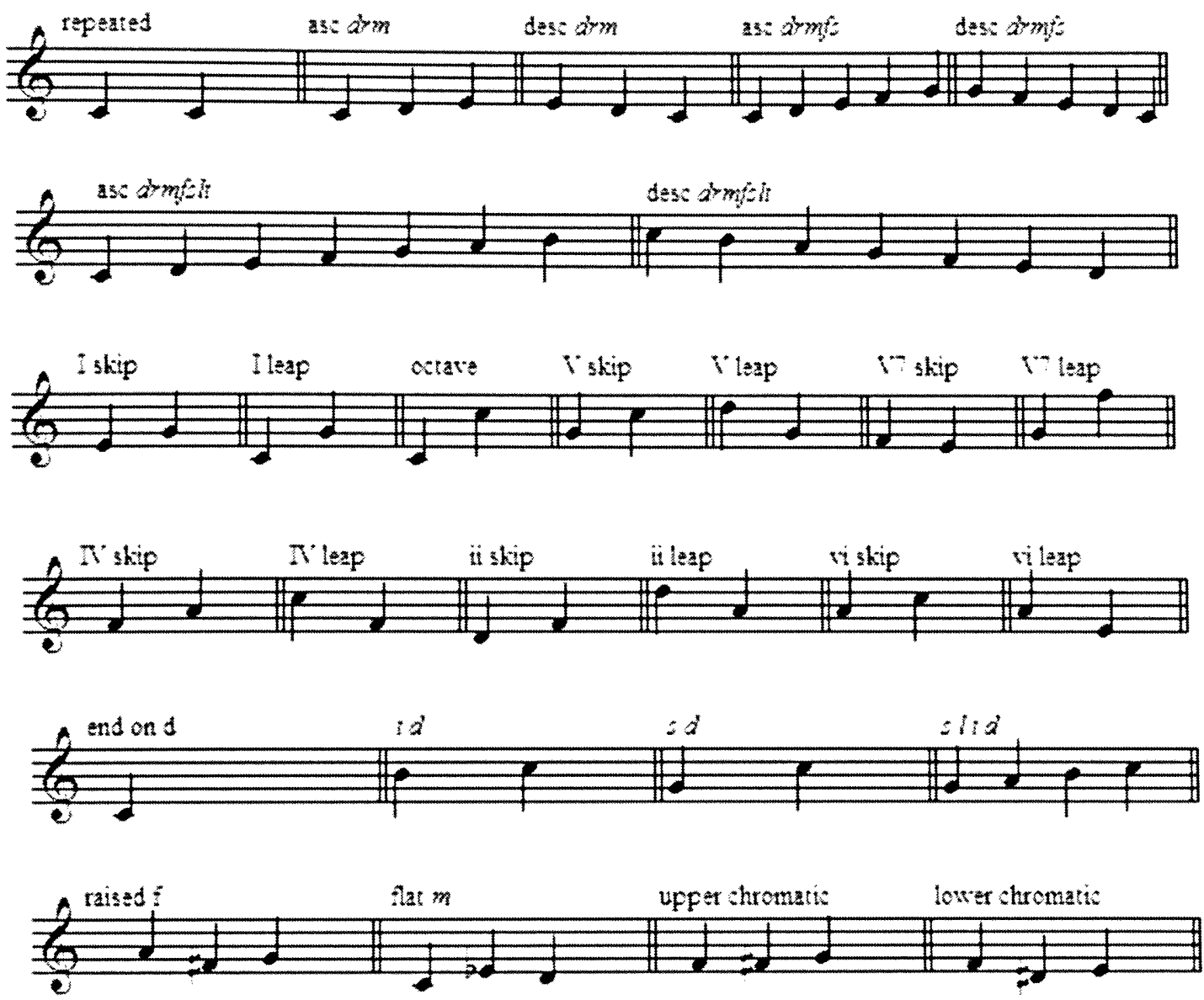
Appendix E

Pre and Post Test 


\section{Plans for administering Pre and Post-test}

1. Teacher will distribute the test paper to each student.

2. Teacher will remind student to observe quarter, half and whole notes.

3. Student will clap through example before singing to resolve any rhythm questions. Since rhythm is not going to be evaluated, teacher will review any errors, if any, due to rhythm.

4. Teacher will press play on mini-disk recorder.

5. Teacher will say, "This is student number _-"

6. Teacher will give student starting pitch with Major chord.

7. Teacher will give two measures of 4 counts to set tempo.

8. Teacher will keep a steady $4 / 4$ beat throughout example using a drum pad.

9. Student will sing example on "loo" syllable.

10. Papers will be collected by the investigator.

11. Tabulation of scores will be determined by three trained musicians after all pre and post tests have been recorded. Student numbers will continue 1-80 for pre and post tests. 
Pre and Post Test

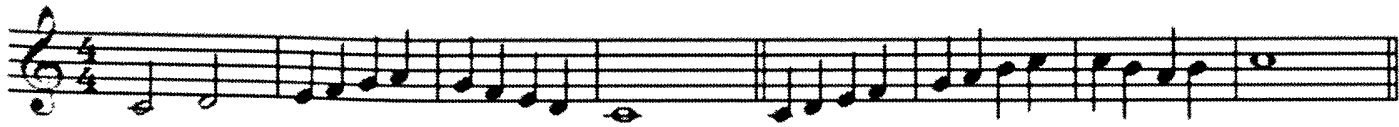


Appendix F

Permission to Reprint 


\section{Global Rights Group}

Servicing rights and permission for Brooks/Cole • Course Technology - Custom Publishing . Detmar Learning - Heinte - Netson Canada - Peterson's * South-Westem - Wadsworth Thomson Learning Global Rights Group 10 Davis Drive, Belmont, Califomia 94002 USA

Phone: 800 730-2214 Fax: 800 730-2215 Emaii: thomsonrights

Merissa Amkraut

Florida International University

8893 Fontainebleau Blvd. \#304

Miami, FL 33172

Thank you for your interest in the following Wadsworth material

Songworks I: Singing in the Education of Children 1st edition

Author(s)

BENNETT/BARTHOLOMEW

ISBN: 0534513271

Publisher: Wadsworth

(C) Year: 1997

Specific material: Figure 6-3 Page 130 "Meloday graph for Mary Had little Lamb" and Figure 6-6 Page 134 Curwen Hand Signs Total pages:

For use by:

Name:

Fulton

School/University/Company: Florida International University

Course title/number: Music Education: Unpublished Masters Thesis

Term of use:

Fall Term 2004

Intended use:

For inclusion in a research project, master's thesis, or doctoral dissertation. May also be stored electronically for on-demand delivery through a dissertation storage system such as UMI system or as listed above. This permission is for non-exclusive rights for the US and Canada in English. Permission extends only to the work specified in this agreement, not to any future editions, versions, or publications. Applicant will not attempt to assign rights given herein to others, and the publication of this material in the work herein approved does not permit quotation therefrom in any other work. If, at a later date, a publishing contract is achieved, additional permission will be required.

The permission granted in this letter extends only to material that is original to the aforementioned text. As the requestor, you will need to check all on-page credit references (as well as any other credit / acknowledgement section(s) in the front and/or back of the book) to identify all materials reprinted therein by permission of another source. Please give special consideration to all photos, figures,

quotations, and any other material with a credit line attached. You are responsible for obtaining separate permission from the copyright holder for use of all such material. For your convenience, we may also identify here below some material for which you will need to obtain separate permission.

This credit line must appear on the first page of text selection and with each individual figure or photo:

From Songworks I. Singing in the Education of Children 1st edition by BENNETT/BARTHOLOMEW. (C) 1997. Reprinted with permission of Wadsworth, a division of Thomson Leaming: www.thomsonrights.com. Fax 800 730-2215.

Sincerely,

Sarah Harkrader

Permissions Editor

Good luck with your project! 